PRACE GEOGRAFICZNE

zeszyt 159, 2019, 25-48

doi: 10.4467/20833113PG.19.018.11486

Instytut Geografii i Gospodarki Przestrzennej UJ

Komisja Geograficzna, Polska Akademia Umiejętności

Wydawnictwo Uniwersytetu Jagiellońskiego

\title{
ADAPTABILITY OF A SOCIO-ECOLOGICAL SYSTEM. THE CASE OF A POLISH MUNICIPALITY AT RISK OF FLOOD
}

\author{
Græegorz Dumieński, Alicja Lisowska, Andræej Tiukato
}

\begin{abstract}
The main objective of the article is to verify the hypothesis that any municipality in Poland, which is at risk of flood, is a socio-ecological system (SES) of a certain level of adaptability. Assessment of adaptability of an SES municipality at risk of flood requires finding such features of the system which have direct impact on the process of its adaptation to the risk and which make useful indicators for assessing current adaptability of a municipality. Based on the research conducted, the article presents four categories of features: human capital and social potential, financial potential, ecological potential and organisation potential, with 15 features within them to describe the adaptability of a municipality-SES in case of flood risk.
\end{abstract}

Keywords: socio-ecological system, municipality, adaptability, flood hazard

\section{Introduction}

Adaptation to climate changes can be affected by various factors, including political, environmental, cultural and economic ones or those related to processes of international relations and security. Furthermore, diverse circumstances which determine adaptation measures depend also on the advancement of adaptation process and previously achieved effects. Adaptation measures, which should be implemented within the pending adaptation process on each level (international level, state, as well as local level), condition the process's success. Adger et al. argue that the success 
of strategic adaptation measures in the future will be determined by the negative impact of extreme natural phenomena which will raise the awareness of climate change within the process of shaping state policies (Adger et al. 2005).

The forecasted climate change concerns the territory of Poland, too (KLIMAT 2012). Therefore, decision-makers on the state level perceive this problem as rational and they have initiated various projects, including Development of Urban Adaptation Plans for cities with more than 100,000 inhabitants in Poland (Polish abbr. MPA). The MPA project involved identification of the main climate hazards for 44 of the biggest cities in Poland (Dumieński et al. 2019) and an analysis in order to identify sensitive sectors of Polish cities and to develop a list of adaptation measures adjusted to particular agglomerations and reducing negative consequences of climate change-related hazards (SPA 2010; IPCC 2012; MPA 2017). It should be highlighted that taking specific adaptation measures, especially on the local level, is a new responsibility of the local government, arising directly from the need to adapt to climate change (Głogowska, Pawlak 2015; Gendźwiłł 2017; Lackowska, Swianiewicz 2017).

With more than $80 \%$ of European cities having low or very low adaptive potential (Dubiel 2016), it is very difficult to choose the most efficient measures to ensure cities' resilience to the progressing climate change (DEFRA 2013). Adaptation to climate change involves very high costs (Ingham, Ulph 2003), but it is economically rational to reduce the negative consequences of currently observed and forecasted extreme natural phenomena related to climate change (including floods) (Dubiel 2016). For example, a failure to take clearly defined adaptive measures in Poland may lead to losses of up to 86 billion PLN until 2020 and a further 119 billion PLN in 2021-2030 (2010 prices) (SPA 2013; Dubiel 2016). Forecasts of increasing frequency and intensity of disastrous phenomena should be taken into account, too (IPCC 2012; Costache 2017). In Poland this concerns especially periods of drought or heavy rains with resultant floods, including flash-flood types (KLIMAT 2012).

The observed impact of climate change on natural and social systems (e.g. McCarthy et al. 2001; Parmesen, Yohe 2003; IPCC 2012; KLIMAT 2012; SPA 2015) has become a starting point of studies assessing the adaptability of socio-ecological systems (SES) with respect to variable natural hazards, including floods (Scheuer et al. 2010). In 2016, the Polish government approved Flood Risk Management Plans for river basin areas and water regions (Polish abbr. PZRP), which provide a catalogue of technical and non-technical measures to limit negative consequences of floods, thus corresponding to the state activity aimed at a reduction of the negative impact of this phenomenon. However, while the PZRP assigned specific levels of flood risk to particular municipalities, their adaptability to flood risk was not assessed. The documents assume that the adaptability is the same (identical) for all flood-hazard municipalities in Poland. 


\section{Research objectives and methods}

The main objective of the article was to verify the hypothesis that any municipality in Poland which is at risk of flood is a socio-ecological system (SES) of a certain level of adaptability. Therefore, it was assumed that a municipality is a specific socio-ecological system which allows establishing a definition of socio-ecological system and its adaptability to flood hazard. As a consequence of these assumptions, the article attempts to identify the system's features which affect the process of its adaptation to the hazard and which may also serve as useful indicators of assessment of the municipality's current adaptability. The research discussed in this paper was also based on the following questions:

- What criteria can be applied to define the basic features of a municipality (as an SES) which determine the efficiency of the process of its adaptation to the (identified and expected) flood risk and to maintain efficiency and effectiveness of processes within the SES aimed at ensuring well-being of its inhabitants?

- What is the impact of the selected features of a municipality as an SES on its adaptability to flood hazard?

The multi-aspect and interdisciplinary character of the research determined the selection of research methods. Thus, considering the concept of a socio-ecological system and a municipality as a unit of territorial government in Poland, the analytical-descriptive method was applied (Hill 1997; Krüger 2005; Trask 2007), along with the normative approach.

Application of the analytical-descriptive method seems necessary, as it combines strengths of a multi-aspect scientific analysis of available literature with the specificity of actually existing features which define the adaptability (or no adaptability) of a municipality at risk of flood. Furthermore, using this method enables conceptualisation, and then operationalisation of the terms of adaptability, as well as the socio-ecological system, considering especially the specific nature of each of the systems: the social and the ecological one.

Another argument for applying this method (the analytical-descriptive one) involves using the system theory to describe a municipality. This theory focuses on indicating the presence of relationships between particular elements (Henderson 1935; Parsons 1991; Luhmann 2005). In accordance to this theory, it was assumed that, firstly, each system has some individual features (features of the socio-ecological system), which, secondly, cannot be reduced to features of particular elements (features of the social system and features of the ecological system), but they are the resultant of the elements' features. Therefore, it means that the socio-ecological system shapes its own attributes it uses to strive to maintain homeostasis, both the internal, and the external one - in relation to other systems. 
For the purpose of developing a complete description of the issue discussed in the article, normative analysis was applied, too (Stelmach 2007). Using this method (normative analysis) allowed indicating the specific nature of Polish municipalities, including municipalities' competencies as units of the local government. This type of analysis is expressed in the defined categories of municipalities' adaptability features, resulting from the existing legal regime, e.g. features within the financial and organisational potential, as well as the diversity of forms of nature protection, included in the ecological potential.

\section{Specific nature of a polish municipality at risk of flood}

Floods are the biggest natural hazard in Poland (Rządowe Centrum Bezpieczeństwa 2013). This is a result of the scale of floods in Poland, as well as the scope of the resulting damage. About $50 \%$ of municipalities in Poland are at risk of flooding with a probability of $\mathrm{p}=1 \%$, i.e., "centenary water" (probability of flood once a century) (Dumieński et al. 2015; Matczak et al. 2016). Further, in many municipalities, the range of flood risk $(\mathrm{p}=1 \%)$ reaches even up to $60 \%$ of their territory (Dumieński et al. 2015), and for many potential flood damages exceed the total annual budgets managed by the respective municipalities (more in: Dumieński et al. 2018a).

What's more, there is a normative reason to select a municipality, which is the basic unit of local government in Poland, as the unit for analysis. It is important to remember that a Polish municipality holds a range of competencies according to the currently binding law on flood protection (more about crisis situations in municipalities cf. Filaber 2016).

Therefore, choosing municipalities as the subject of the research corresponds to the postulate concerning involvement of local authorities in operations aimed at adapting local administrative units to identified hazards (Gendźwiłł 2017). It should be stressed that local and regional authorities are institutionally and politically responsible for protecting citizens, and they are at the first line of reaction in crisis situations - ensuring basic services and supervision, as well as managing disasters, if they actually occur. Local and regional authorities are responsible for prevention and immediate reaction, as well as rescue operations, and above all - they have detailed knowledge about the locality and community. Local and regional authorities are also in charge of reconstruction after a crisis (Dziennik Urzędowy Unii Europejskiej 2017). 


\section{Municipality as a socio-ecological system facing flood hazard}

Socio-ecological system (SES) is a term which was originally defined as a system of two strictly interrelated basic components of the geographical space which affect each other - both its natural resources and human capital, determined by cultural, political and economic factors (Holling 1973). Bunge (1979) added more precise requirements for a definition of a system, stating that a minimal description of a system requires a definition of its three aspects: composition, environment and structure. Composition of a system is a set of its parts, elements and components, while environment is a set of objects which are not elements of the system but are associated to the system; and structure is a set of the system's actual relations, especially correlations between components of the system as well as between the system and its environment (Bunge 1979). The concept of SES was also analysed by e.g., Berkes and Folke (1998), Folke (2004), Gallopin (2006), Moser and Ekstorm (2010) and Birkmann (2013).

In the Polish specialist literature on the subject, the term socio-ecological system (SES) was analysed by Degórski (2010), who used Holling's definition (1973) to additionally indicate that the SES's environment includes a broadly defined economic sphere, which determines directions of the region's development (Degórski 2010). According to Degórski (2010), it is especially interesting to analyse the functioning of SES in areas which constitute the same geographic region, artificially divided into administratively separate, although physiognomically and naturally uniform structural units, which very frequently modify or even disturb historical spatial relations, functional and cultural connections. In the Polish context, a municipality is exactly such a region and it was also a subject of study related to the research of SES, described by Dumieński and Tiukało (2016).

However, considering the dynamics of change within contemporary societies, as well the natural environment, with respect to the subject of the research it seems necessary to define more precisely the term of SES itself, correlations between the components of SES (i.e., the social and ecological systems), and to suggest a catalogue of determining factors which define the efficiency of the functioning of SES, despite the existence of extreme natural phenomena, e.g., floods.

Therefore, SES was defined as a set of two systems: the social system and the ecological system which depend on each other in their functioning. The subject (or the element) of SES in its social aspect is a human individual functioning in variable communities, e.g., society, organisations, institutions (municipality) or social groups. The ecological aspect, in turn, is shaped with biotic elements of nature (natural environment and anthropogenic elements). These entities form a network of interactions, interdependencies and connections, striving to the broadly defined development of SES. 
In the study, the researchers assumed that the basic purpose of the social system is to achieve a certain level of social well-being, arising from various social agreements and arrangements, constituted and/or approved by participating individuals. The purpose of the ecological system, meanwhile, is a constant need to survive, determined by what this system actually is. Therefore, it was eventually assumed that the purpose of SES is social progress considering the durability of the ecological system which can be achieved by shaping social attitudes and needs and by satisfying those needs and ensuring the possibility to maintain the ecosystem's functions. At the same time, social attitudes, with respect to the ecological system (arising from the self-assessment of the community's condition, among other factors), finally determine the nature of development of SES, which can be either sustainable or not. Hence, there are social attitudes present in the SES which constitute a set of emotions, actions and knowledge of the local communities and shape the SES' capacity of self-organisation and undertaking specific tasks in order to achieve a major goal (e.g. in a crisis situation), but also in order to maintain the relevant condition of its natural environment.

SES' capacity to achieve various goals depends on various factors: social, political, economic, cultural, historical and international ones, as well as environmental factors (including climate and biodiversity). The effectiveness of SES' achievement of the goal is affected also by multiple functions of the ecological system versus the social system, among them:

- practical function which involves provision of natural resources serving to produce economic goods and energy,

- ancillary function, involving possibility to reduce flood hazard, assimilate contamination (absorption of side effects of human social and economic activity) (Matczak 2000) and

- aesthetic and cultural functions related to individuals' possibilities to experience natural beauty and contact with nature (Bukowska-Gorgoni, Pruszyński 1974).

The effectiveness of accomplishment of particular goals of SES is determined also by specific attributes of the social subsystem related to the human and social capital, as well as organisational, economic and ecological potential, and finally the ecological subsystem's resilience (or non-resilience) to contemporary environmental hazards.

In the light of the above considerations, it is possible to treat a municipality as an SES shaped by the local community residing in a predefined area, as well as particular components of the natural environment along with anthropogenic elements which function in the same area.

In order to achieve the set goals effectively (those related to the functioning of the social system and ecological system, too) individuals residing at the area in question self-organise by establishing various organs, entities or institutions. In this context, municipal organs are important for the municipality's survival as an SES. Those 
organs undertake relatively permanent, sensible, sovereign and planned actions aimed at achieving particular functions, needs and interests, values and ideas in the social and environmental (ecological) aspect (more in: Lisowska 2017). Specific acts of law binding in this area are of importance, too.

Municipal authorities have access to particular types of tools (e.g., legal, economic and political ones) which affect both residents of the respective territory and components of the natural environment located within the administrative unit in question.

Municipal authorities' impact on the municipality as an SES is mainly due to the scope and content of competencies and responsibilities of these authorities with respect to the broadly defined environmental protection (as set in various legal acts). Some of them concern municipalities' operations related to environmental protection, while others define in detail their activities in the environmental aspect considering various circumstances, such as climate change or floods. Poland has relatively recently formulated actions with respect to climate change which describe many initiatives (SPA 2013) to be implemented in the environmental sphere by municipalities. Flood risk management is one of those initiatives. In this context, it is worth highlighting that flood protection in each municipality is organised by taking into account the Flood Hazard Maps (Polish abbr. MZP), Flood Risk Maps (Polish abbr. MRP) and Flood Risk Management Plans (Ustawa z dnia 20 lipca 2017).

However, effective and efficient actions by a municipality to cope with natural hazards, including floods, are held not only through the shaped system of responsibilities and norms assigned to particular organs of the municipality, they are also based on activities by other entities within the municipality. The capacity of municipalities to cope with flood prevention as well as reduction of a flood's negative impact is also reflected in non-institutional measures. It is primarily about a municipality as a local community shaped by its residents being able to establish a specific adaptive capacity, specific level of resilience to the diagnosed and forecasted flood hazard. The resilience allows for applying the available skills and resources of the municipality in order to reduce flood risk. These are such determining factors of municipalities' adaptability which gain importance in special situations, such as a flood. In practice, such factors, shaped within the adaptation process, may define the municipality's ability to manage flood risk.

The conceptual scheme of assessment of flood hazard assessment of a socio-ecological system, as presented in fig. 1, is based on the assumption that any such system is characterised by the scale of exposition of its elements to flood (presented on flood hazard maps etc.) and their vulnerability to this phenomenon. A flood as a factor which disturbs SES' functioning, may display variable intensity at a given probability. Exposition refers to all elements of SES which are vulnerable to flood and located in the flood hazard area. Sensitivity involves characteristics (features) of SES' elements exposed to flood hazard which make flood a cause 


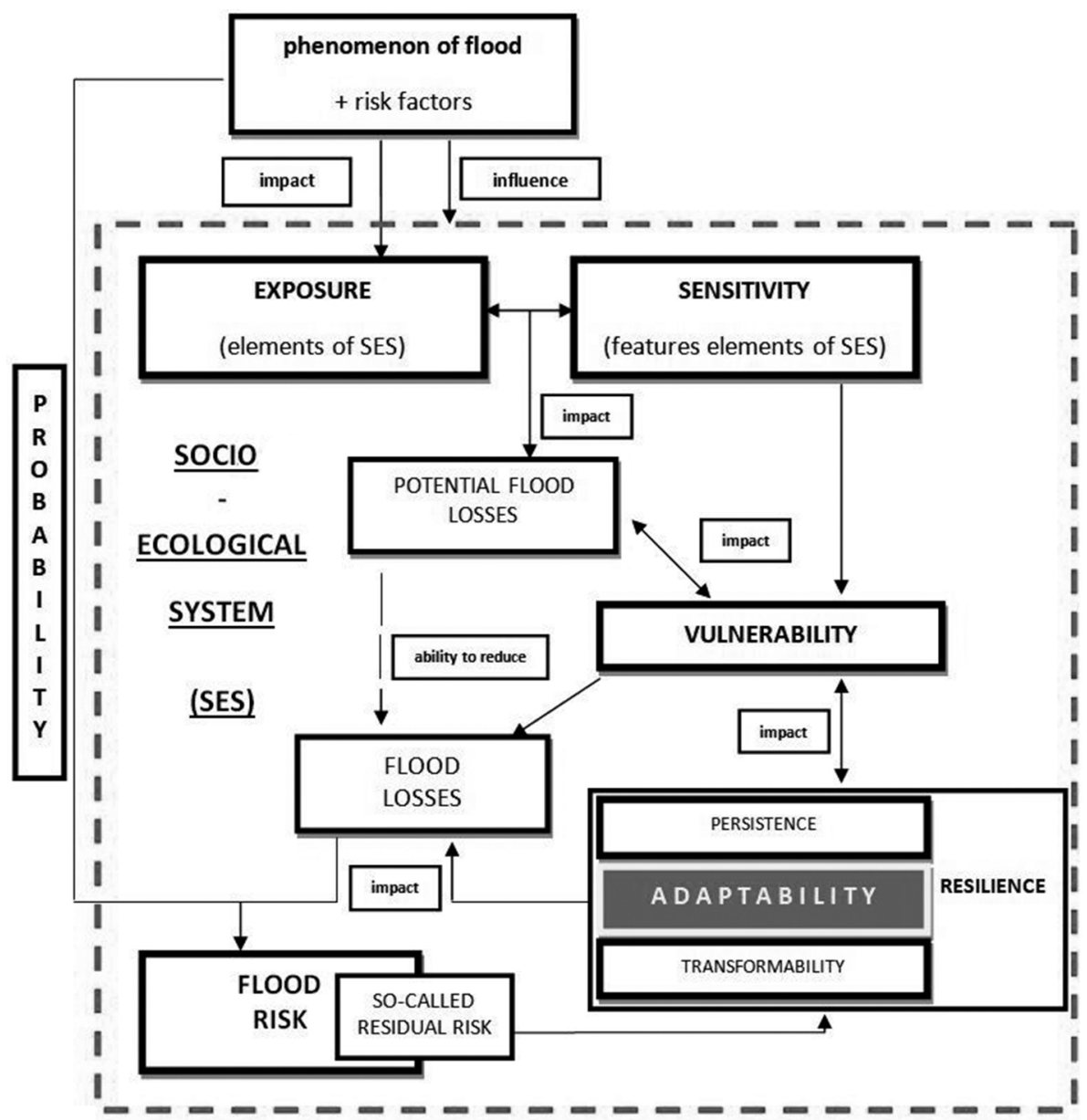

Fig. 1. Algorithm for assessing the flood risk of a socio-ecological system at risk of flood, indicating the role of the system's adaptability in risk reduction Source: originally developed based on Dumieński, Tiukało 2017.

of various damages. Both exposition and vulnerability of elements of the system at risk of flood are affect the scale of potential damage due to a flood. However, the final scale of the damage is determined by the system's vulnerability, shaped by resilience of the system at risk of flood. Resilience of a system is defined as its ability to reduce negative consequences in a stress situation and it includes durability of the system (in the context of change, buffer capacity, withstanding shocks), its adaptability 
and capacity to transform (in the case if the negative consequences and scale of the disaster force the system to transform its basic functions).

\section{Adaptation and adaptability of a municipality as a socio-ecological system}

Adaptation is a complex, permanent set of defined actions and processes aimed at adapting to changing conditions (Smit et al. 2000).

Authors of definitions of adaptation, as discussed by Sienkiewicz-Małyjurek (Sienkiewicz-Małyjurek 2015) and others (Millenium Ecosystem Assessment 2005; Smit et al. 2006; Gersonius 2012; MPA 2017), highlight that adaptation is treated as a process subject to a predefined goal. It should be noted that some definitions of adaptation suggest that the objective of adaptation process is not only to reduce a system's susceptibility to observed or expected hazards, but also to use the occurring opportunities related to changes in the functioning conditions of the system in question (Moser, Ekstorm 2010). Moser and Ekstorm (2010) stress that these changes may sometimes (but not always) have negative consequences, too.

In the specialist literature on the subject, other definitions of adaptation can be found, too, focusing on its final effect, i.e., the achievement of a specific level of adaptability to the expected conditions of functioning of the system in question. This type of definitions of adaptation actually identify adaptation with adaptability (e.g. Gallopin 2006, Folke et al. 2010).

There was also a definition of adaptation developed within the Intergovernmental Panel on Climate Change (IPCC 2012), which provided that adaptation is adjustment to actual or expected climate and its effects, in order to moderate harm or exploit beneficial opportunities. However, the IPCC's definition separates natural and social systems, therefore in the present paper the definition by Moser and Ekstorm (2010) will be applied: Adaptation involves changes in socio-ecological systems in response to actual and expected impacts of climate change. Considering the specific nature of research discussed in this paper, concerning a municipality as a socio-ecological system at risk of floods, the above definitions (IPCC 2012; Ekstorm, Moser 2010) have been modified as follows: a municipality's adaption to flood hazard is a managed or free process aimed at making the municipality resistant to flood hazard, while the course of the process is determined by the variable features of the municipality.

In the context of the suggested definition of SES adaptation in the case of a municipality at risk of a flood, adaptability of an SES can be defined as the SES-municipality's ability to reduce negative consequences of floods achieved as a result of the adaptation process. This way of understanding adaptability 
is also in line with the definition by Walker et al. (2009) considering adaptability as the capacity to adjust to the changing conditions and ability of the systems' participants to impact its resilience.

The main factors determining adaptability of a municipality (SES) at risk of flood are:

- adaptive potential, taking into account the quantity and quality of resources the municipality has and

- adaptive capacity, or the capacity to activate the held resources in order to manage

flood risks in the municipality sensibly.

Adaptability of a municipality at any stage of its development can be assessed by its adaptive potential and adaptive capacity identified at the moment of assessment. Hence, one may conclude that adaptability characterises the condition of the particular system at the moment of assessment.

In view of the above considerations and for the purpose of original research, the authors applied the following definition of adaptability of a municipality as a socio-ecological system at risk of flood: the system's current capacity to activate its resources in order to reduce negative impact of floods. This definition highlights that a system's adaptability is constantly changing as a result of the adaptation process (within the SES). The process of adaptation shapes the adaptive potential and adaptive capacity of an SES. Still, the adaptive potential of a socio-ecological system results from specific features of the system in question and its elements, as well as resources it holds and can use in the process of adaptation (to increase its adaptability). Meanwhile, the adaptive capacity of a socio-ecological system is an effect of specific features and predispositions of the system related to activation of its adaptive potential. Adaptive capacity depends on the form of organisation of the community on each level and on the skills and coordination of activities by competent entities, including institutions within the municipality (Gendźwiłł 2017).

Assuming that a socio-ecological system (e.g. a municipality) holds certain resources, then adoptive capacity means the ability to use them effectively in the process of adaptation. The process of adaptation brings a higher level of adaptability of thus defined socio-ecological system (municipality).

It should be highlighted that some researchers (e.g. Gersonious 2012) treat systems' adaptability and adaptive capacity as equivalent. If adaptability as a certain condition of the system within the process of adaptation is not differentiated from the factors that shape it (adaptive potential and adaptive capacity), it may have an adverse impact on analyses within particular case studies. According to Birkmann (2011), adaptive capacity is connected to political and social relations. Skomra (2015) perceives adaptive capacity as a state's or its regions' ability to adjust to hazards or reduce them, especially through reduction of impact or probability of a disaster, defining adaptive capacity as the ability to manage risk. 
The definition of adaptive capacity of a municipality-SES at risk of flood takes into account arguments presented in the following publications: Moser (2008) which defines social capacity as the ability to introduce variable changes, sometimes deep and structural ones which help systems adjust better to long-term transformations in social and environmental areas; as well as the approach to adaptive capacity as the overall ability of institutions, systems and individuals to adjust to potential damage in order to use chances or cope with consequences (Millenium Ecosystem Assessment 2005) or also as the systems' ability to evolve in order to adjust to environmental hasards, concerning also changes in management structures which allow increased flexibility of the system (Sienkiewicz-Małyjurek 2015). The authors of the quoted definitions refer to the institutional, management-related aspect which is very important in the case of a municipality perceived as an SES.

Each municipality as a socio-ecological system has multiple objectives. In the developed definition of an SES at risk of flood, it was assumed that the priority objective of a municipality as an SES is to achieve social progress considering the durability of the ecological system. A flood as a phenomenon, along with its negative impact, interferes with the possibilities to achieve those objectives of a municipality-SES. This means that the definition of the determining factors of municipalities' adaptability which affect the adaptive potential and adaptive capacity of an SES (the main factors of adaptability) allows for assessment of the current level of this specific feature (adaptability) of the system (municipality).

Development of a tool to assess the level of adaptability of a municipality as an SES to flood hazards will allow for planning and taking measures to stimulate effectiveness and efficiency of the process of reducing the municipality's vulnerability to hazards. Furthermore, the possibility to apply such a tool may serve to support management processes in defining the objectives of adaptation (and methods to achieve them) which consequently lead to reducing the flood risk and increased capacity to achieve specific objectives of the municipality-SES.

\section{Features which determine adaptability of a municipality-ses at risk of flood}

In the research area related to flood risk, many variable methods were applied to order features of socio-ecological systems which affect its specific characteristics, e.g. vulnerability (e.g. Walczykiewicz 2014; Działek et al. 2017), sensitivity (e.g. Rucińska 2015; Werner et al. 2015; Dumieński, Tiukało 2016) or adaptive capacity (including: Scheuer et al. 2011; Hahn, Nykvist 2017). As noted by Kuhlicke et al. (2011), there is a need to build a capacity of coping with natural threats in societies for which these threats may bring adverse consequences in economic, social and environmental areas. Therefore, social capacity (Kuhlicke et al. 2011) 
is a property of the social system (as an element of the socio-ecological system) shaping its resilience to various threats.

For conducting the research on assessing adaptability of a municipality at risk of flood, it was useful to note that a municipality perceived as a socio-ecological system has a range of features which determine the process of adaptation to flood hazard and that these features may by classified. In this article, the investigated features of a municipality-SES determining its adaptability to flood hazard, were classified in four categories:

C1 human capital and social potential,

C2 financial potential,

C3 ecological potential,

C4 organisational potential.

It should be stressed that the adaptive potential of a municipality is described by the features classified in the first three categories (human capital and social potential, financial potential, ecological potential - 6.1, 6.2, 6.3 respectively), while the adaptive capacity of a municipality as a system is described by the features in the categories: human capital and social potential and organisational potential (6.1, 6.4, respectively).

Selection of the features of a municipality-SES which affect its adaptability to flood hazard, included in the four categories, was guided by postulates that such features should:

- take into account the main attributes of the social system and the ecological system, and

- indicate the current and expected challenges associated with the systems' functioning.

Furthermore, the identified features of an SES which affect its adaptability to flood hazard were confronted with features affecting the social system's social ability to shape its resilience, developed by the research team of Kuhlicke et al. (Kuhlicke et al. 2011; Kuhlicke et al. 2012). This team presented 6 categories of features of the social system which shaped social capacity in confrontation with natural threats. The identified categories of social capacity included: knowledge capacity, motivational capacity, economic capacity, institutional capacity, procedural capacities, network capacities. Their definition by Kuhlicke et al. (2011) is presented in the last column of tables (tables 1-4).

\section{Features which determine the adaptability of a municipality-SES within the category of features of human capital and social potential}

Human capital includes all features which affect productivity of an individual, including education, intelligence and innate talents, as well as connections which affect 
human performance and work efficiency (Kotarski 2013). In the applied methodology of original research of adaptability of Polish municipalities (SES) at risk of flood, human capital is an analytical term perceived with respect to three areas of activity of municipalities: health, education (Sztompka 2002) and civilisation (Szacki 2002) ${ }^{1}$.

It means that the planned catalogue of determining factors of municipalities' adaptability must involve characterisation of a municipality not only through its social and demographic profile of its inhabitants, but it should also refer to various resources held by the municipality which define quality of life of its inhabitants.

Meanwhile, the social potential means the community's capacity to undertake various types of activities. These activities may be reflected in forms of organisation of the social life (including political life), the residents' shaping of and participation in the cultural life of a municipality-SES, as well as the capacity to react to crisis situations.

Thus, in the category of human capital and social potential, six features affecting adaptability of a municipality-SES were identified:

- F1 health capital,

- F2 educational capital,

- F3 civilisation capital,

- F4 ability to identify crisis situations and react to them,

- F5 ability to organise social life (including political life),

- F6 cultural potential.

The features of a municipality-SES included in the category of human and social capital are discussed in table 1.

\section{Features which determine the adaptability of a municipality-SES within the category of features of financial potential}

A municipality's financial potential involves its capacity to acquire financial resources and to use them effectively to implement its objectives considering a reduction of flood risks (Dumieński et al. 2018a).

In the discussed category, three features affecting the adaptability of a municipality-SES to flood hazard were defined:

\footnotetext{
${ }^{1}$ For the purpose of the applied classification of the features of adaptability of a municipality (SES), Alfred Weber's definitions of culture and civilisation were used (Szacki 2002). According to Weber civilisation a process of rationalisation and intellectualisation of human life leading to improvement of life opportunities, aspirations and methods of their satisfaction. It is the overall attainment in technique, science and art. Culture means language, customs, symbols, values, ideas, modes of reacting, feeling, thinking, architecture, art - everything that affects thinking and acting of the community in question, all elements by which the community defines itself and its identity (Sztompka 2002). Therefore, this differentiation of terms results in division of the category of human capital and social potential into features characteristic for civilisational as well as cultural aspect of the municipality's activity.
} 


\begin{tabular}{|c|c|c|c|c|c|c|}
\hline 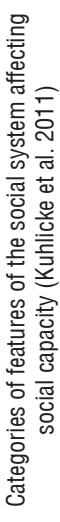 & & 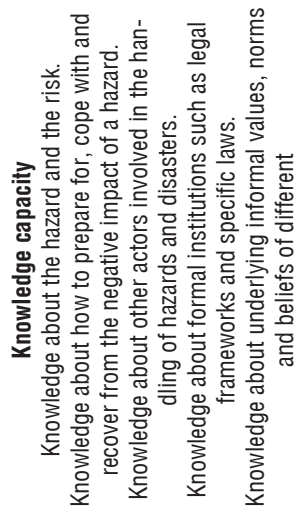 & & \multicolumn{2}{|c|}{ 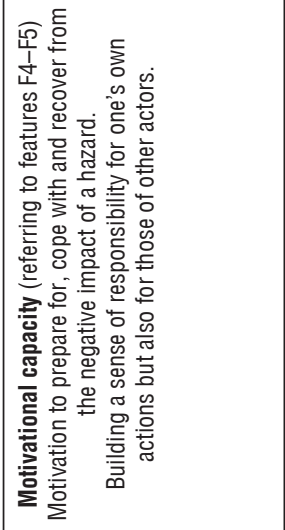 } & \\
\hline 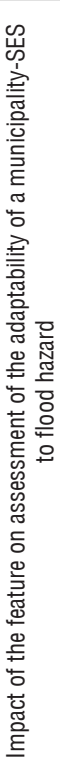 & 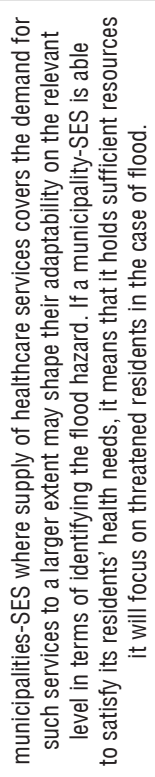 & 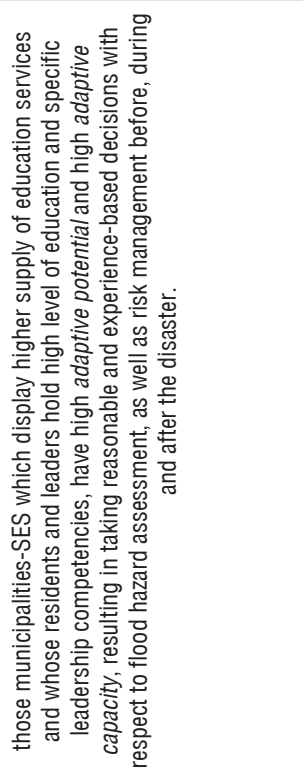 & 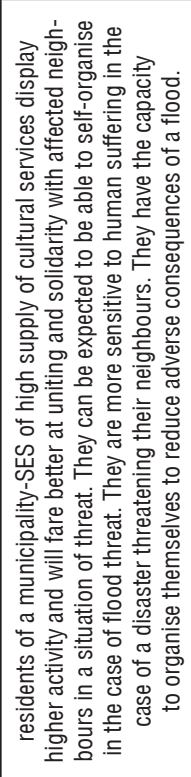 & 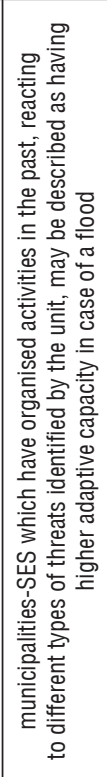 & 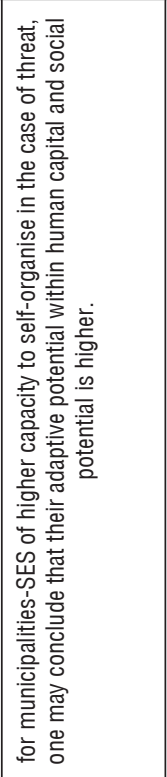 & 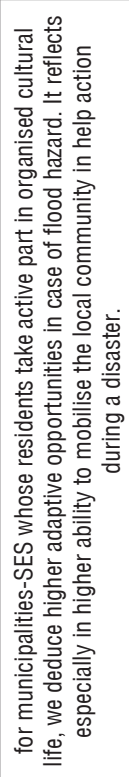 \\
\hline & 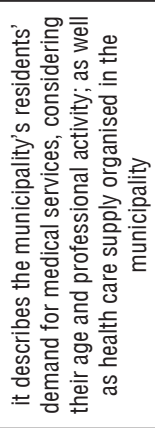 & 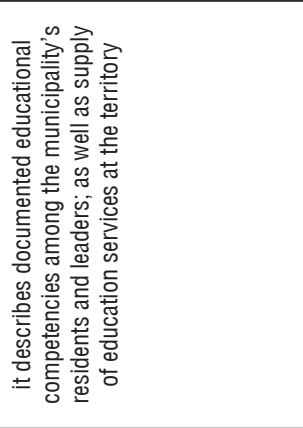 & 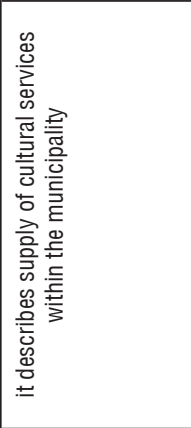 & 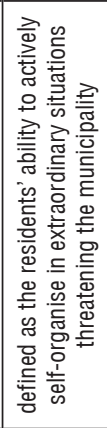 & 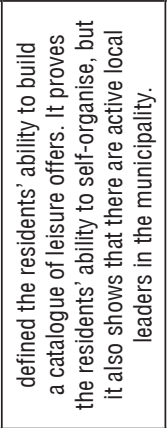 & 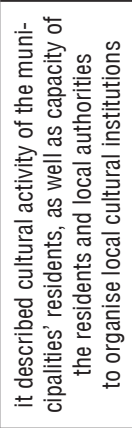 \\
\hline 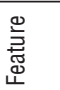 & Б & $\widetilde{\leftarrow}$ & $\mathscr{P}$ & 过 & 난 & 电 \\
\hline
\end{tabular}


- F7 relevance of the structure of municipal budget with respect to the identified hazard,

- F8 municipality's ability to operate its liabilities,

- F9 municipal budget per capita.

The features of a municipality-SES included in the category of financial potential are discussed in table 2.

\section{Features which determine the adaptability of a municipality-SES within the category of features of ecological potential}

Ecological potential involves possibilities or predispositions of an ecological system allowing for its survival in crisis situations (e.g., flood). As highlighted in the definition of the socio-ecological system in chapter 4 , the specific objective of the ecological subsystem is to survive. Therefore, in this category it is important to define the determining factors of municipalities' adaptability and presence of potential sources of environmental contamination in the flood risk area in the municipality.

Therefore, in the category of ecological potential the following three features affecting the adaptability of a municipality-SES were defined:

- F10 variability of forms of development,

- F11 diversity of forms of environmental protection,

- F12 risk of environmental potential sources (Bedryj et. al. 2018).

The features of a municipality-SES included in the category of ecological potential are discussed in table 3.

\section{Features which determine the adaptability of a municipality-SES within the category of features of organisation potential}

Organisational potential is reflected in the quality of organisational structures and binding law, in a certain type of thinking among local decision-makers and elites (including strategic thinking) and ability to organise the local community and external environment of the municipality for efficient and effective management of the community in a crisis situation.

In this category, three features affecting the adaptability of a municipality-SES were defined:

- institutional potential,

- ability to organise the local community,

- ability to organise the external environment.

The features of a municipality-SES included in the category of organisational potential are discussed in table 4. 


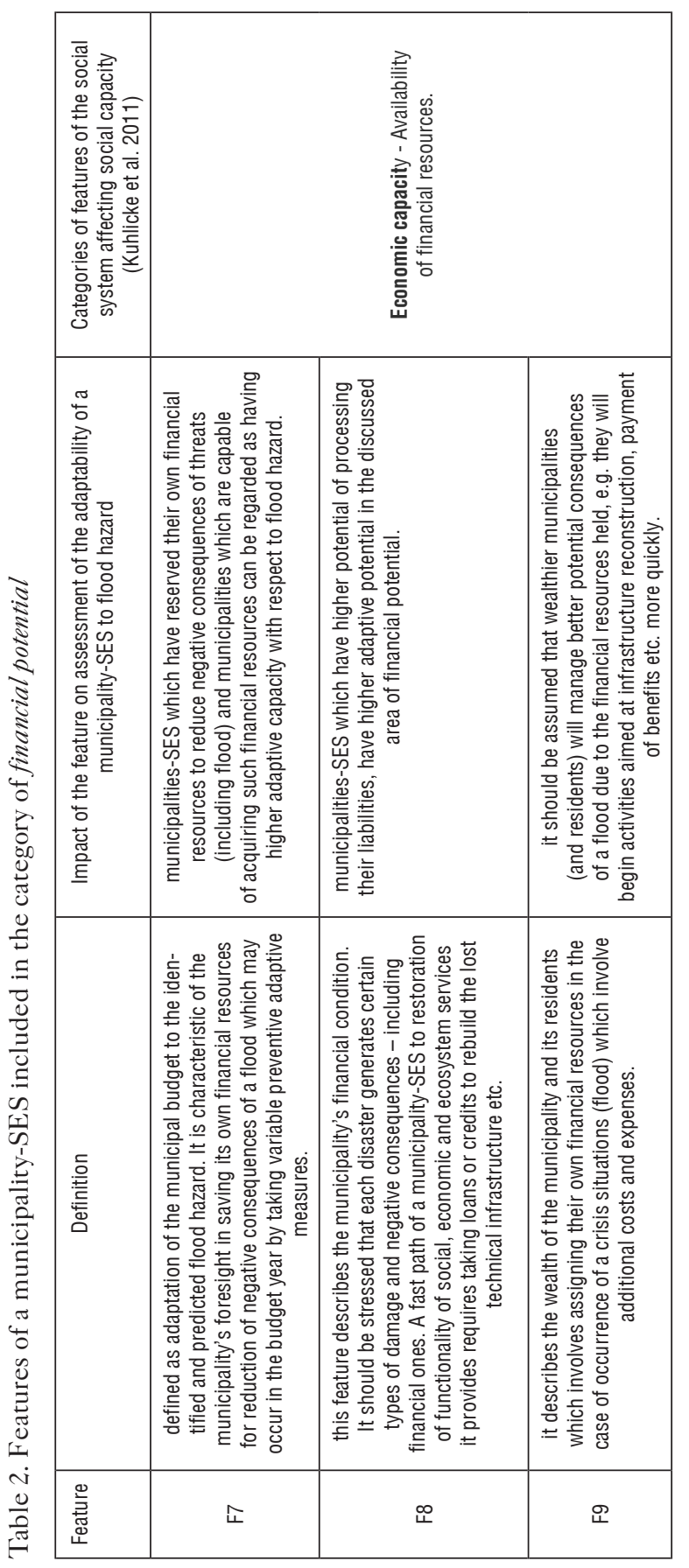

\begin{tabular}{|c|c|c|c|}
\hline 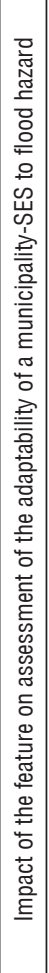 & 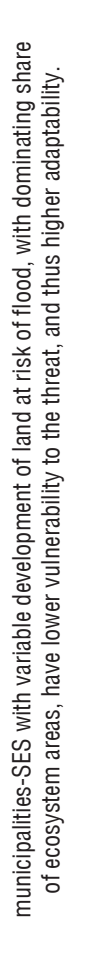 & 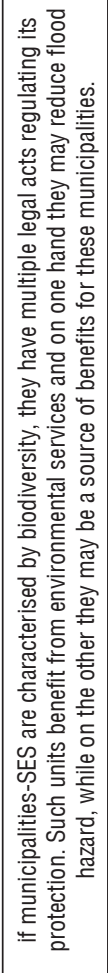 & 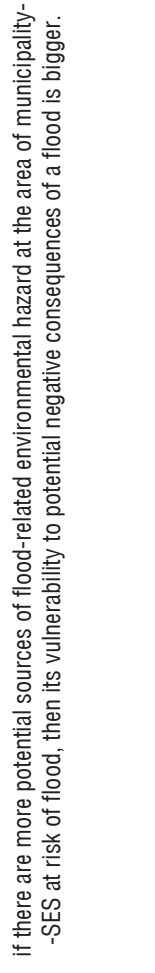 \\
\hline $\begin{array}{l}\text { 흘 } \\
\text { 言 } \\
\text { 言 }\end{array}$ & 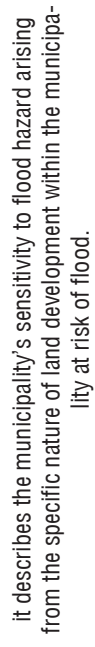 & 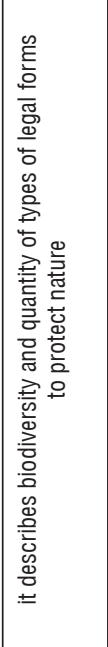 & 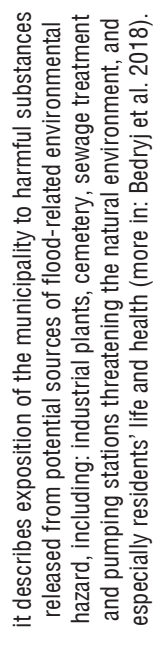 \\
\hline 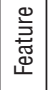 & $\dot{u}$ & $\dot{L}$ & $\dot{L}$ \\
\hline
\end{tabular}




\begin{tabular}{|c|c|c|c|c|}
\hline 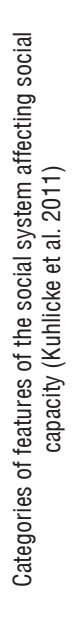 & \multicolumn{2}{|c|}{ 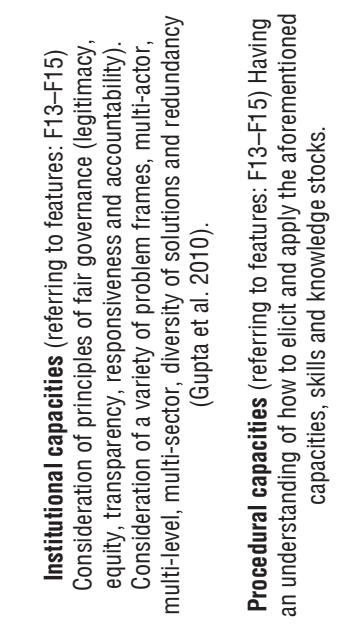 } & \multicolumn{2}{|c|}{ 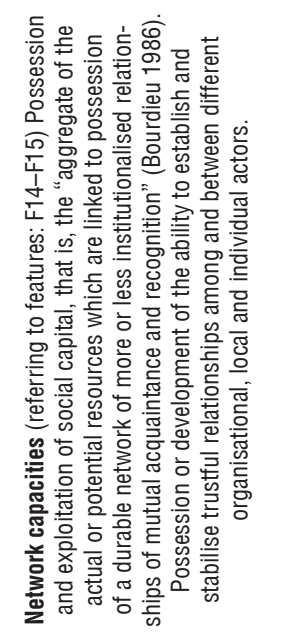 } \\
\hline 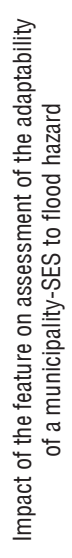 & 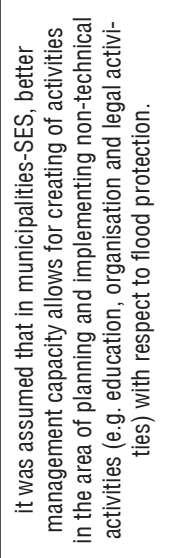 & 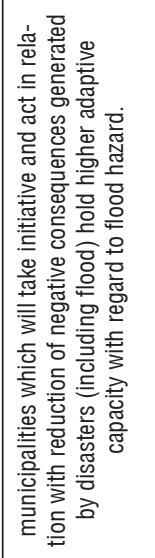 & & 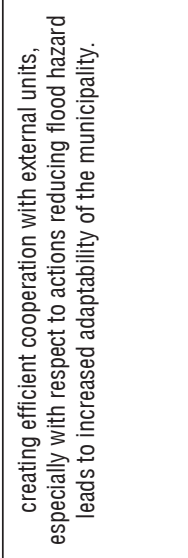 \\
\hline 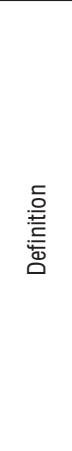 & 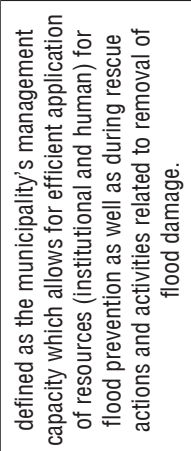 & 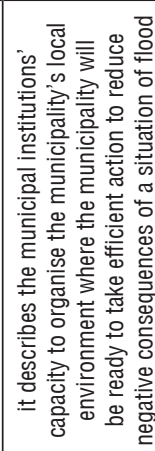 & 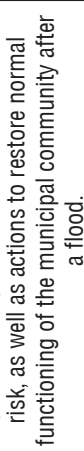 & 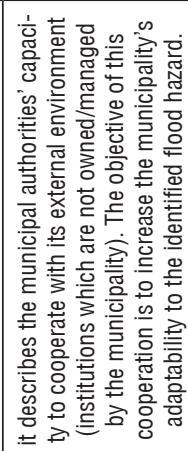 \\
\hline 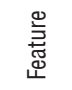 & 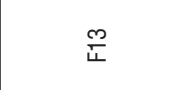 & 亡 & & $\frac{10}{\square}$ \\
\hline
\end{tabular}


The set of social capacities presented by Kuhlicke et al. (2011) corresponds with features affecting an SES' adaptability to flood hazard, as selected by the authors. It should be stressed that different terminology may be applied within methods of assessment adaptability of a municipality as a socio-ecological system at risk of flood, as selected by the authors (the authors' explorations concerns specific capital/ potential, while Kuhlicke et al. (2011) refer to resources/capacities), however, their understanding or classification is similar or identical (e.g. knowledge capacity vs. educational capacity). For example the feature of educational capital (F2) may be conditionally identified with the category of knowledge capacity, as long as curricula contain knowledge of areas involved in the definition provided by Kuhlicke et al. (2011). Unfortunately, the level of education of the residents of Polish municipalities does not translate to knowledge capacity, because school curricula in Poland do not contain knowledge referred to by Kuhlicke et al. (2011).

In the case of the economic capacity category suggested by Kuhlicke et al. (2011), its description focuses on "availability of financial resources". In the present article, the category was described in more detail by including three features to reflect a municipality's financial condition, as well as the wealth of its residents and its capacity to consider consequences of flood hazard in budget construction.

In the category of organisational potential (C4), the authors identified three features: institutional potential (F13), ability to organise the local community (F14) and ability to organise the external environment (F15), while Kuhlicke et al. (2011) defined three categories corresponding to this concept of the authors. These are: network capacities, institutional capacities and procedural capacities. The authors claim that separation of institutional and procedural capacities as applied by Kuhlicke et al. (2011) is conventional as these two features are very strongly related (in the Polish situation this is also due to the binding normative regime). Therefore, the authors covered these categories of social capacities by Kuhlicke et al. (2011), i.e. institutional and procedural capacity by a single feature: institutional potential (F13). In the present article, the institutional potential (F13) refers to network capacities and institutional capacities (Kuhlicke et al. 2011).

Kuhlicke et al. (2011) did not investigate a separate ecological aspect due to the scope of their analyses which concerned the social system. Therefore the set of 6 categories of features of the social system which affect social capacity, as presented by Kuhlicke et al. (2011), corresponds to three categories of features of the social system defined by the authors: human capital and social potential (C1), financial potential (C2), organisational potential (C4), as well as to most of features of a municipality included in these three categories to describe its adaptability. 


\section{Conclusions}

For the purposes of original research, the article attempted to redefine such terms as the socio-ecological system (SES) and adaptability with respect to the analytical category of a municipality at risk of flood. Adaptation of these terms resulted in a necessity to order some related terms, such as adaptation, adaptive capacity or adaptive potential.

The study confirmed the thesis that any Polish municipality at risk of flood may be analysed as a socio-ecological system. It should be noted that in Poland a municipality, defined as an SES, is a major actor implementing various actions of the local level which serve to increase its adaptability in view of the identified flood hazard.

Finally, fifteen features which determine the adaptability of a socio-ecological system (municipality) were defined within four categories. These features shape the system's adaptive capacity and adaptive potential. The authors believe that the selected features may be also useful for assessment of the adaptability of another SES similar to the investigated one, they may also be used for analyses in the context of other types of natural hazards (e.g. drought). Therefore the authors consider the recommended set of features to be universal. Figure 2 presents the four categories including the 15 features which determine the adaptability of an SES to flood hazard.

It should be noted that the suggested catalogue of 15 features affecting the adaptability of a socio-ecological system (municipality) is not a closed list. This means that the provided set of determining features can be modified. It can be broadened to include other criteria or else it can be narrowed by elimiantion of some factors listed in the proposition.

The research conducted by the authors, aimed at development of a tool to allow assessment of the adaptability of municipalities as socio-ecological systems to flood hazard was then focused on identification and selection of variables (indicators) which could enable description of the listed features. The set of indicators was defined in detail based on information obtained in the public sphere (from the databases of Statistics Poland etc.), as well as based on a specifically developed questionnaire (Dumieński et al. 2020). The tested research area covered by a preliminary assessment of adaptability included 18 municipalities located within of the sub-basin of Nysa Kłodzka. The resultant rating of the adaptability of these units to flood hazard was presented in the work by Dumieński and his collaborators (Dumieński et al. 2018b).

This work was financially supported by Development of Urban Adaptation Plans for Cities with more than 100.000 inhabitants in Poland (Polish abbr. MPA). The project is financed by the European Union from The Cohesion Fund and the state budget as part of technical assistance for the Infrastructure end Environment Program. 
The authors also want to thank the reviewers of the originally submitted paper, whose remarks and suggestions are reflected in the current version.

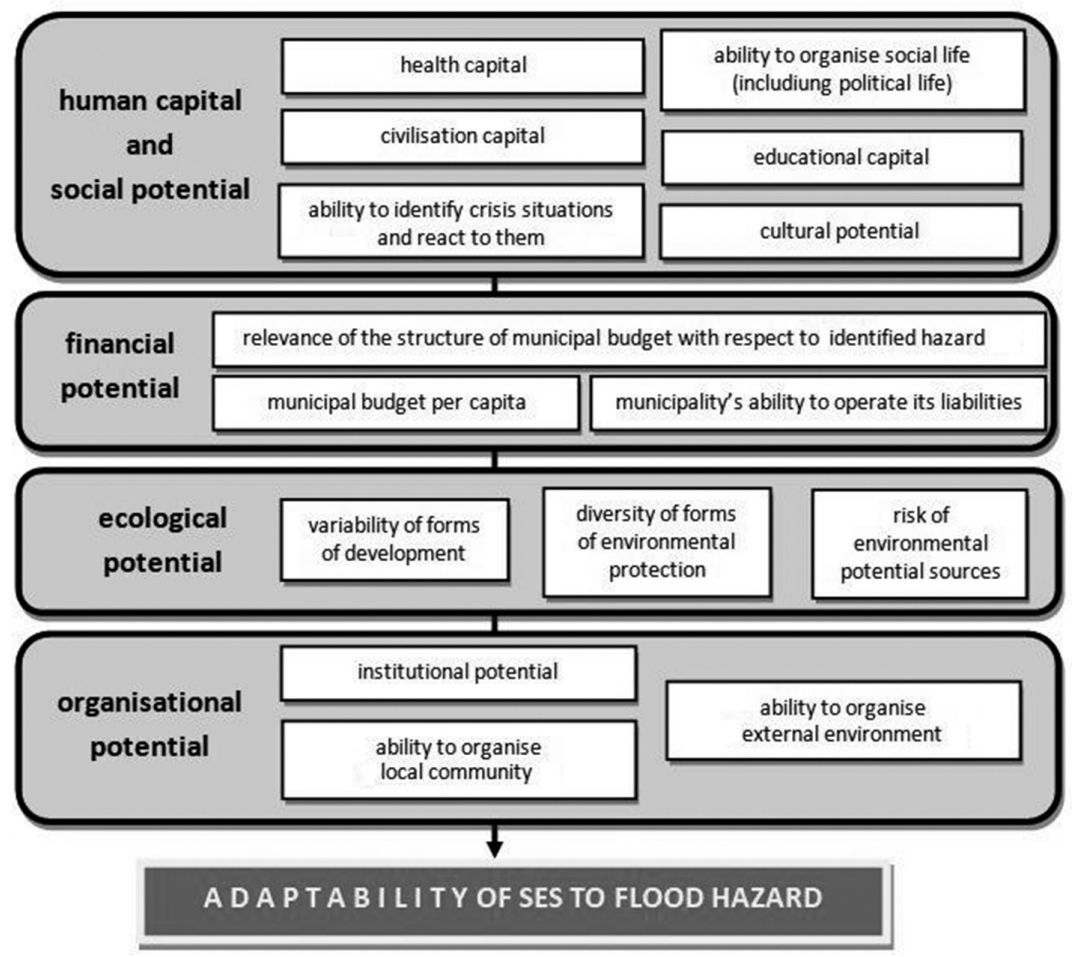

Fig. 2. Features affecting the adaptability of a municipality as a social-ecological system (SES) to flood hazard classified in four categories

\section{References:}

Adger W.N., Arnell N.W., Tompkins E.L., 2005, Successful adaptation to climate change across scales, Global Environmental Change, 15 (2), 77-86.

Bedryj M., Dumieński G., Tiukało A., 2018, Potential threat to Polish lakes and reservoirs from contamination by objects of environmental flood risk, Limnological Review, 18 (4), 137-147.

Berkes F., Folke C. (ed.), 1998, Linking social and ecological systems: management practices and social mechanisms for building resilience, Cambridge Univ. Press.

Birkmann J., 2011, First- and secondo-order adaptation to natural hazards and extreme events in the context of climate change, Natural Hazards, 58 (2), 813. 
Birkmann J., 2013, Measuring vulnerability to promote disaster-resilient societies and to enhance adaptation: Conceptual framework and definitions [in:] J. Birkmann (ed.), Measuring vulnerability to natural hawards: towards disaster resilient societies, United Nation University Press, 9-54.

Bourdieu P., 1986, The forms of capital [in:] J.G. Richardson (ed.), Handbook of theory and research for the sociology of education, Greenwood Press, New York, 248.

Bukowska-Gorgoni K., Pruszyński J.P., 1974, Środowisko naturalne a dobra kultury, Studia Iuridica, 2, 115.

Bunge W., 1979, Perspective on theoretical geography, Annals of the Association of American Geographers, 69 (1), 4.

Costache A., 2017, Conceptual delimitations between resilience, vulnerability and adaptive capacity to extreme events to global change, Annals of Valahia University of Targoviste. Geographical Series, 17 (2), 198-205.

DEFRA Department for Environemnt, Food \& Rural Affairs, 2014, Defra annual report and accounts 2013 to 2014, http://www.gov.uk/government/publications (dostęp: 17.08.2018).

Degórski M., 2010, Uwarunkowania środowiskowe systemu spotecæno-ekologic»nego na pogranicæu polsko-niemieckim jako wewnętrænej granicy Unii Europejskiej, Problemy Ekologii Krajobrazu, 26, 11-24.

Dubiel A., 2016, Finansowanie kosætów zapobiegania i adaptacji do smian klimatu, Ekonomia i środowisko, 3 (58), 101-110.

Dumieński G., Pasiecznik-Dominiak A., Tiukało A., 2015, Społeczno-ekonomiczna ocena zagro¿̇enia powodziowego gmin w Polsce [w:] K. Piekarska, A. Kotowski, B. Kaźmierczak (red.), Interdyscyplinarne zagadnienia w inżynierii i ochronie środowiska, 6, Oficyna Wydawnicza Politechniki Wrocławskiej, Wrocław, 100-125.

Dumieński G., Tiukało A., 2016, Gmina jako system społecะno-ekologicæny zagro:̇ony powodziq [w:] B. Kaźmierczak, A. Kotowski, K. Piekarska (red.), Interdyscyplinarne zagadnienia w in:ynnierii i ochronie środowiska, 8, Oficyna Wydawnicza Politechniki Wrocławskiej, Wrocław, 67-79.

Dumieński G., Tiukało A., 2017, The measurement of the adaptive capacity of the social-ecological system towards flood haward [in:] $3^{\text {rd }}$ Disaster Risk Reduction Conference (DRR) Warsaw (Poland), 12-13 October 2017.

Dumieński G., Krzyżanowski M., Tiukało A., 2018a, Municipalitie's financial potential and flood policy, E3S Web of Conference, 44, 00037, 1-8.

Dumieński G., Mruklik A., Tiukało A., Lisowska A., 2018b, Preliminary research on adaptability of municipalities in the sub-basin of Nysa Ktodzka using multidimensional comparative analysis, ITM Web of Conferences, 0008, 1-8.

Dumieński G., Lisowska A., Tiukało A., 2019, Zagrożenia klimatyczne 44 miast w Polsce na podstawie miejskich planów adaptacji do zmian klimatu [w:] L. Chojnacka-Ożga, H. Lorenc (red.), Wspótczesne problemy klimatu Polski, Instytut Meteorologii i Gospodarki Wodnej, Państwowy Instytut Badawczy, Warszawa, 189-201.

Dumieński G., Lisowska A., Tiukało A., 2020, Badania ilościowe śódtem danych o adaptacyjności gmin sagrożonych powodziq w zlewni Nysy Ktodzkiej (in review process). 
Działek J., Biernacki W., 2014, Wrażliwość spoteczna na klęski żywiołowe - ujęcie teoretyczne i praktyka badawc:a, Prace i Studia Geograficzne, 55, 27-41.

Działek J., Biernacki W., Konieczny R., Fiedeń Ł., Franczak P., Grzeszna K., Listwan-Franczak K., 2017, Zanim nadejdzie powód※. Wptyw wyobrażeń przestrzennych, wrażliwości spotecznej na klęski sywiołowe oraz komunikowania ryzyka na przygotowanie spoteczności lokalnych do powodzi, IGiGP UJ, Kraków.

Dziennik Urzędowy Unii Europejskiej, 2017, Opinia Europejskiego Komitetu Regionów - Plan dziatania w sprawie ram \& Sendai dotyczacych ograniczania ryzyka klesk sywiotowych w latach 2015-2030 - podejscie oparte na ryzyku klęsk żywiotowych dla wszystkich strategii politycznych UE, C 272/32 PL.

Filaber J., 2016, Ochrona be«pieczeństwa publičnego w gminie, Wydawnictwo Difin, Warszawa, 61-107.

Folke C., 2004, Traditional knowledge in social-ecological systems, Ecology \& Society, 9 (3), 8.

Folke C., Carpenter S.R., Walker B., Scheffer M., Chapin T., Rockstorm J., 2010, Resilience thinking: integrating resilience, adaptability and transformability, Ecology \& Society, 15 (4), 20.

Gallopin G.C., 2006, Linkages between vulnerability, resilience, and adaptive capacity, Global Environmental Change, 16 (3), 293-303.

Gendźwiłł A., 2017, Zdecentralizowana adaptacja? Opinie władz lokalnych o smianach klimatu i lokalnej polityce adaptacji do zmian, Studia Regionalne i Lokalne, 2 (68), 30-49.

Gersonius B., 2012, The resilience approach to climate adaptation applied for flood risk, CRC Press/Balkema, 25-28.

Głogowska M., Pawlak J., 2015, Adaptation to climate change as a task for local authorities, Environmetal Protection and Natural Resources, 3 (65), 42-48.

Gupta J., Termeer C., Kostermann J., S. Meijerink, van den Brink M., Jong P., Nooteboom S., Bergsma E., 2010, The adaptive capacity wheel: a method to assess the inherent characteristics of institutions to enable the adaptive capacity of society, Environmental Science and Policy, 13, 459-471.

Hahn T., Nykvist B., 2017, Are adaptations self-organized, autonomous, and harmonious assessing the social-ecological resilience literature, Ecology \& Society, 22 (1), 12.

Henderson L.J., 1935, Paretos general sociology, Cambridge.

Hill M., 1997, The Policy process in the modern state, London.

Holling C.S., 1973, Resilience and stability of ecological systems, Annual review of ecology and systematics, 4 (1), 1-21.

IPCC, 2012, Managing the risks of extreme events and disasters to advance climate change adaptation.

A special report of working groups I and II of the Intergovernmental Panel on Climate Change, Cambridge University Press, Cambridge, UK and New York, NY, USA, 556.

Ingham A., Ulph A., 2003, Uncertainty, irreversibility, precaution and the social cost of carbon, Working Paper 38, Tyndall Centre for Climate Change Research, University of East Anglia, Norwich.

KLIMAT, 2012, Projekt KLIMAT, http://klimat.imgw.pl (dostęp: 10.07.2018).

Kotarski H., 2013, Kapitat ludzki i kapitat spoteczny a rozwój województwa podkarpackiego, Wydawnictwo Uniwersytetu Rzeszowskiego, Rzeszów, 12-13. 
Krüger H.H., 2005, Wprowadzenie w teorie i metody badawcze nauk o wychowaniu, GWP, Gdańsk. Kuhlicke C., Steinfuhrer A., Begg C., Bianchizza C., Brundl M., Buchecker M., De Marchi B., Di Masso-Tarditti M., Hoppner C., Komac B., Lemkowe L., Luther J., McCarthy S., Pellizzon L., Renn O., Scolobig A., Supramaniam M., Tapsell S., Wachinger G., Walker G., Whittle R., Zorn M., Faulkner H., 2011, Perspectives on social capacity building for natural ha:ards: outlining an emerging field of research and practice in Europe, Environmental Science Policy, 14, 804-814.

Kuhlicke C., Steinfuhrer A., Begg C., Luther J., 2012, Toward more resilient societies in the field of natural hazards: CapHaw-Net's Lesson Learnt, CapHaw-Net WP10 final report, Helmholtz Centre for Environmental Research - UZF; Leipzig \& Johann Heinrich von Thunen Institute.

Lackowska M., Swianiewicz P., 2017, Czynniki warunkujqce preferencje i dziatania samorzqdów gminnych w Polsce w zakresie tagodzenia i adaptacji do zmian klimatycznych, Prace Geograficzne, $149,55-80$.

Lisowska A., 2017, Cechy polityki ochrony środowiska w Polsce na poziomie gminy, Samorząd Terytorialny, 4 (316), 49-55.

Luhmann N., 2005, Sociologische Aufklärung 2. Aufsätze zur Theorie der Gesellschaft, Wiesbaden, 9-62.

Matczak P., 2000, Problemy ekologiczne jako problemy spoteczne, Wydawnictwo Naukowe UAM, Seria Socjologia, Poznań, 27, 32-33.

Matczak P., Wiering M., Lewanowski J., Schellenberger T., Tremorin J.B., Crabbe A., Ganzevoort W., Kaufmann M., Larrue C., Liefferink D., Mees H., 2016, Comparing flood risk governance in six European countries: strategies, arrangements and institutional dynamics (report no. D4.1.), STAR-FLOOD Consortium, Utrecht, The Netherlands.

McCarthy J.J., Canziani O.F., Leary N.A., Dokken D.J., White K.S. (ed.), 2001, Climate change 2001: Impact, adaptation, and vulnerability, Cambridge University Press, United Kingdom, 877-912.

McEvoy D., Lonsdale K., Matczak P., 2008, Adaptation and mainstreaming of EU climate change policy: An actor-based perspective, CEPS Policy Brief, 149, 1-13.

Millenium Ecosystem Assessment, 2005, Ecosystems and human well-being: Policy responsens, Washington DC: Island Press, 599.

Moser S.C., 2008, Resilience in the face of global environmental change, CARRI Research Report 2, CARRI, Oak Ridge.

Moser S.C., Ekstrom J.A., 2010, A framework to diagnose barriers to climate change adaptation, PNAS, 107 (51), 22026-22031.

MPA Miejskie Plany Adaptacji do Zmian Klimatu 2017, Metodyka opracowania projektu Miejskiego Planu Adaptacji na podstawie oferty do Zamówienia pn. Opracowanie planów adaptacji do zmian klimatu w miastach powyżej 100 tys. mieszkańców; zasób własny IMGW-PIB, Warszawa.

Parmesen C., Yohe G., 2003, A globally coherent fingerprint on climate change impacts across natural systems, Nature, 421 (6918), 37-42.

Parsons T., 2009, System społeczny, Zakład Wydawniczy NOMOS, Kraków (org. pub. 1951). 
Rucińska D., 2015, Kwantyfikacja podatności na zagrożenia naturalne. Præeglad metod, Prace i Studia Geograficzne, 57, 43-53.

Rządowe Centrum Bezpieczeństwa 2013, Powódঞ. W obliczu zagrożenia, RCB, Warszawa, 3.

Scheuer S., Haase D., Meyer V., 2010, Exploring multicriteria flood vulnerability by integrating economic, social and ecological dimensions of flood risk and coping capacity: from a starting point view towards and end point view of vulnerability, Natural Hazards, 58 (2), 731-751.

Sienkiewicz-Małyjurek K., 2015, Skuteczne sarzqdzanie kryzysowe, Wydawnictwo Difin, Warszawa, 218.

Skomra W. (ed.), 2015, Metodyka oceny ryzyka na potrzeby systemu zarzqdzania kryzysowego RP, Bel Studio, Warszawa, 20.

Smit B., Burton I., Klein R.J.T., Wandel J., 2000, An anatomy of adaptation to climate change and variability, Climate Change, 45 (1), 223-251.

Smit B., Wandel J., 2006, Adaptation, adaptive capacity and vulnerability, Global Environmental Change, 16 (3), 282-292.

SPA Strategiczny Plan Adaptacji, 2013, Strategiczny plan adaptacji dla obszarów wrażliwych na zmiany klimatu do roku 2020, zperspektywa roku 2030, Ministerstwo Środowiska, Warszawa, 60.

Stelmach J., 2007, Analiza ekonomicะna w sastosowaniach prawniczych, Wydawnictwo Wolters Kluwer, Warszawa.

Szacki J., 2002, Historia myśli socjologicznej. Wydanie nowe, Wydawnictwo Naukowe PWN, Warszawa, 704-707.

Sztompka P., 2002, Socjologia. Analiza spoteczeństwa, Wydawnictwo Znak, Kraków, Rozdział X, XI. Trask R.L., 2007, Language and linguistics: The key concepts, Routledge.

Ustawa z dnia 20 lipca 2017 r. Prawo wodne (Dz.U. 2017 r. poz. 1566).

Walczykiewicz T., 2014, Metodyka kwantyfikacji wra:̇liwości jako jednego z czynników wptywajqcych na ryzyko powodziowe, Temat badawczy DS-W 1.2 zadanie 3, zasób własny IMGW-PIB, Kraków, 60-92.

Walker B.H., Abel N., Anderies J.M., Ryan P., 2009, Resilience, adaptability, and transformability in the Goulburn-Broken Catchment, Australia, Ecology \& Society, 14 (1), 12.

Werner P., Magnuszewski A., Rucińska D., Porczek M., 2015, Zró̈nicowanie præestrzenne wrażliwości spotečnej na «agrożenie powodziowe w Polsce, Prace i Studia Geograficzne, 57, 67-74.

Grzegor: Dumieński

Institute of Meteorology and Water Management - National Research Institute

ul. Podleśna 61,01-673 Warszawa

grzegorz.dumienski@imgw.pl

Alicja Lisowska

University of Wroctaw, Institute of Political Science

ul. Koszarowa 3, 51-149 Wroctaw

alicja.lisowska@uwr.edu.pl

Andræej Tiukato

Institute of Meteorology and Water Management - National Research Institute

ul. Podleśna 61,01-673 Warszawa

andræej.tiukalo@imgw.pl 